\title{
Archaeocyaths from South America: review and a new record
}

\author{
P. D. GONZÁLEZ ${ }^{*}{ }^{*}$, M. F. TORTELLO ${ }^{2}$, S. E. DAMBORENEA ${ }^{2}$, M. NAIPAUER ${ }^{3}$, A. M. SATO ${ }^{1}$ \\ and $R$. VARELA ${ }^{1}$ \\ ${ }^{1}$ Centro de Investigaciones Geológicas (UNLP-CONICET), La Plata, Buenos Aires, Argentina \\ ${ }^{2}$ División Paleozoología Invertebrados, CONICET, Museo de Ciencias Naturales, La Plata, Buenos Aires, Argentina \\ ${ }^{3}$ Instituto de Estudios Andinos "Don Pablo Groeber", Departamento de Ciencias Geológicas, FCEN-UBA, Buenos
}

Aires, Argentina

\begin{abstract}
In South America, autochthonous archaeocyathan faunas preserved in Early Cambrian limestones have not been found yet. Nevertheless, a few well-documented occurrences of these fossils in clasts contained in coarse-grained rocks of a wide age range have been discovered in recent years. Erratic limestone blocks from the Late Carboniferous-Early Permian Fitzroy Tillite Formation in the Falkland/Malvinas Islands yielded three archaeocyath taxa. Also, seven taxa were reported from archaeocyathan limestone clasts in a metaconglomerate of the Cambro-Ordovician El Jaguielito Formation in northern Patagonia. In addition, a new record from the Late Carboniferous-Early Permian Sauce Grande Formation diamictites in Sierras Australes, Buenos Aires Province, Argentina, is presented herein. Preservation of this scarce new material is poor, but at least three different taxa can be distinguished. The most likely source of all archaeocyathan limestone clasts found in southern South America is the Shackleton Limestone from the Transantarctic Mountains in East Antarctica. The new record from the Sauce Grande Formation and the inferred clast provenance reinforce the correlation between this unit, the Dwyka Tillite (South Africa) and the Fitzroy Tillite Formation (Falklands/Malvinas), suggesting a very wide distribution of these Antarctic occurrences during the Late Carboniferous-Early Permian Gondwana glaciation (Episode III). Thus, even though being allochthonous, archaeocyaths are emerging as a new key biological feature for Gondwana palaeogeographic reconstructions. Copyright @ 2012 John Wiley \& Sons, Ltd.
\end{abstract}

Received 8 July 2011; accepted 5 December 2011

KEY WORDS archaeocyaths; South America; Gondwana; Late Palaeozoic glaciations; Sierras Australes; Buenos Aires

\section{INTRODUCTION}

Archaeocyaths were Cambrian reef-building organisms associated with carbonate-dominated environments in sub-tropical regions (Hill, 1972; James and Debrenne, 1981; Debrenne, 2007). The occurrence of archaeocyaths within sedimentary successions is important because: (1) they are high-quality indicators of maximum depositional age, (2) they have limited palaeogeographic distributions, and (3) they are robust markers of provenance.

Although in southern Gondwana they are well known from the Australo-Antarctic (or 'Gondwana' after Debrenne and Kruse, 1989) palaeobiogeographic province, within South

\footnotetext{
*Correspondence to: P. D. González, Centro de Investigaciones Geológicas (Universidad Nacional de La Plata-CONICET), Calle 1 \#644, B 1900 TAC, La Plata, Buenos Aires Province, Argentina.

E-mail: gonzapab@cig.museo.unlp.edu.ar

†Present address: CONICET-Instituto de Investigación en Paleobiologóa y Geología. Universidad Nacional de Río Negro. Isidro Lobo y Belgrano. CP 8332, Roca, Río Negro Province, Argentina.

E-mail: pablo.diego.gonzalez@gmail.com
}

America there had only been some controversial mentions, such as those from the Precordillera (Rusconi, 1951, 1952) and from Tierra del Fuego (Hyades, 1887). Well-documented specimens have been described in recent years from the Falkland/Malvinas Islands (Stone and Thomson, 2005) and Patagonia (González et al., 2011a). In the Falkland/Malvinas Islands the Archaeocyaths occur in limestone erratic clasts within the Late Carboniferous-Early Permian Fitzroy Tillite Formation diamictites, whereas in Patagonia, they appear instead, in limestone clasts within a Cambro-Ordovician metaconglomerate. The original limestone beds are not exposed near those regions, and therefore the clasts are considered allochthonous.

In addition to this, we report here newly found allochthonous archaeocyath specimens in limestone clasts from the Late Carboniferous-Early Permian diamictites of the Sauce Grande basin, Sierras Australes of Buenos Aires Province, Argentina (Figures 1 and 2). They occur within the context of the same glaciation that affected Gondwana prior to its Mesozoic break-up.

Here we summarize the geological and stratigraphical context of the archaeocyathan occurrences in South America, 


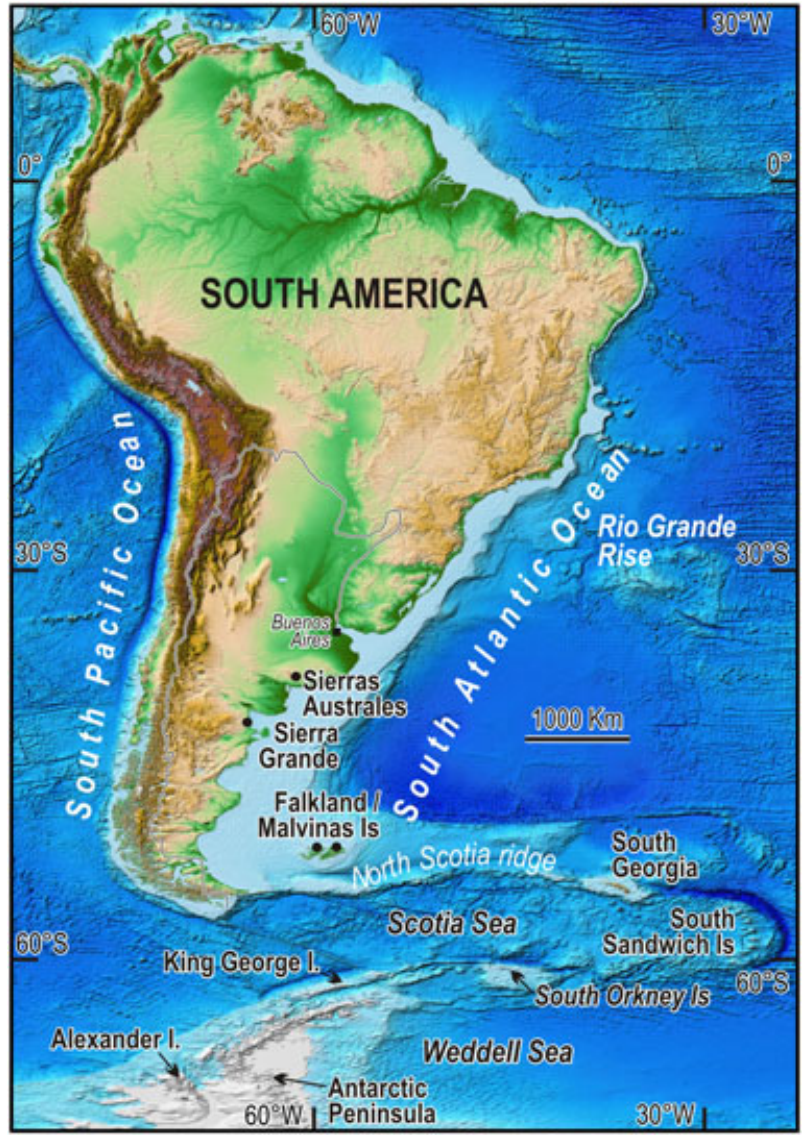

Figure 1. Colour shaded-relief image of South America, Antarctic Peninsula and surroundings from ETOPO-1 Ice Surface (Amante and Eakins, 2009) showing a general overview for the allochthonous archaeocyathan faunas in South America (Patagonia, Sierras Australes and Falkland/Malvinas Islands). Web-site of ETOPO-1: http://www.ngdc.noaa.gov/mgg/global/global.html This figure is available in colour online at wileyonlinelibrary.com/journal/gj

document the newly found specimens from Sierras Australes, and discuss their palaeogeographical implications within the Late Palaeozoic Gondwana glaciation episodes.

\section{GEOLOGICAL OUTLINE OF ARCHAEOCYATH RECORDS}

Within South America (Figure 1), archaeocyaths have been recorded from the Falkland/Malvinas Islands (Stone and Thomson, 2005) and from Sierra Grande area in North Patagonian Massif (González et al., 2011a). A brief description of both the geology and stratigraphy of these records are given below.

\subsection{Falkland/Malvinas Islands}

Archaeocyath fossils from the Falkland/Malvinas Islands (Stone and Thomson, 2005) were found in erratic blocks

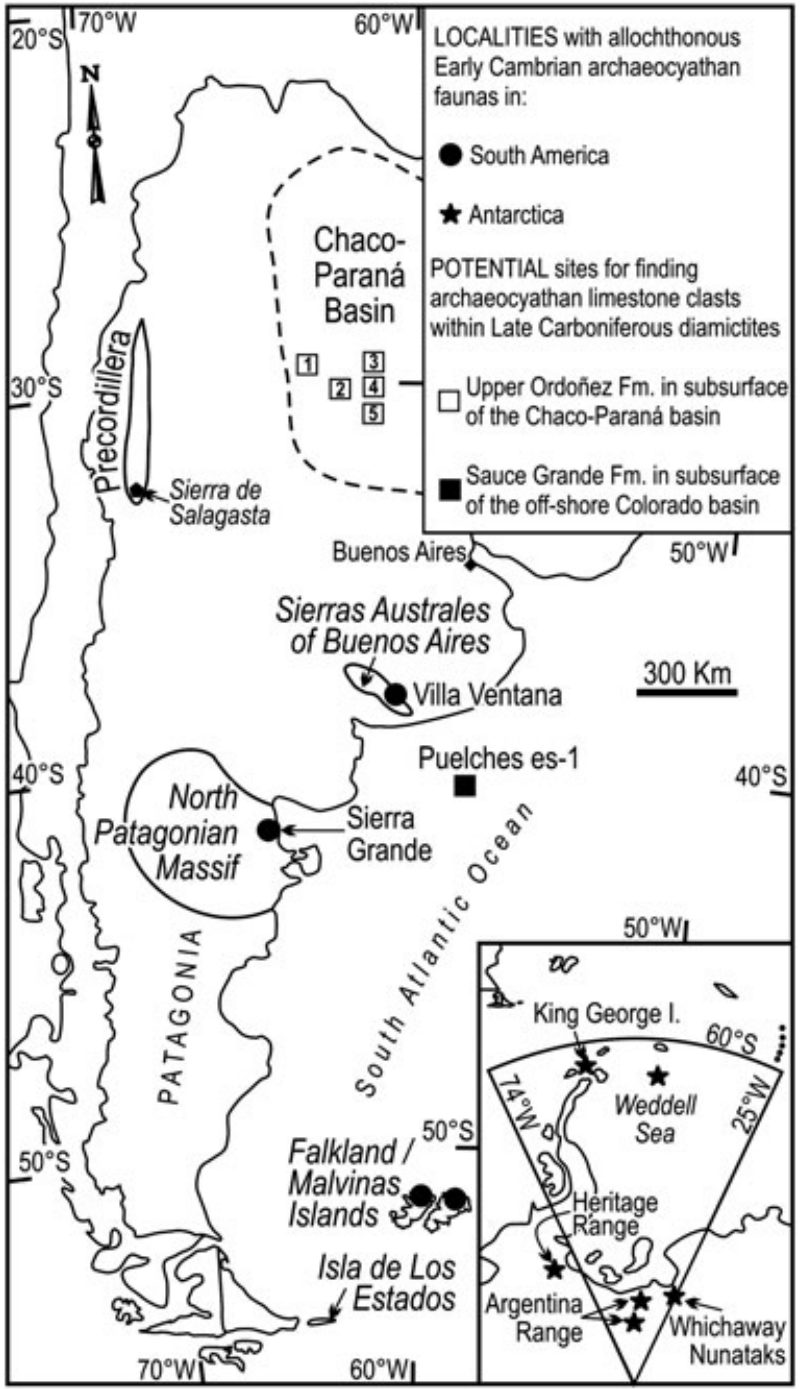

Figure 2. Sketch map depicting the main locations cited in the text. Numbers in Chaco-Paraná Basin indicate locations of the boreholes: (1) Santiago Temple, (2) Ordoñez, (3) Josefina, (4) Saira and (5) Camilo Aldao.

of limestone within the Lafonian Diamictite (Baker, 1924, in Frakes and Crowell, 1967) or Fitzroy Tillite Formation (Aldiss and Edwards, 1999, in Stone and Thomson, 2005), which overlies Siluro-Devonian sandstones and quartzites. The tillites are part of the widespread glaciation that affected Gondwana during the Late Carboniferous to Early Permian (Veevers and Powell, 1987).

According to Frakes and Crowell (1967), massive, grey and brown diamictites with sandy argillaceous matrix and dispersed, boulder- to sand-size clasts are the dominant facies in the Fitzroy Tillite Formation. Bed thickness and maximum clast size vary, respectively, from $850 \mathrm{~m}$ and boulders $7 \mathrm{~m}$ across in the west, to $350 \mathrm{~m}$ and boulders $2 \mathrm{~m}$ across in the east. The lithological variation suggests grounded ice in the west (present coordinates), as evidenced by intercalations of linear and fan-shaped sand bodies 
interpreted as eskers and outwash-fans, and an open-sea with floating ice in the east, as suggested by bedded intercalations of pebbly mudstone, graded greywacke and shale with dropstones. An intermediate, downslope deposit is inferred by the presence of contorted and disrupted sandstone slabs (Frakes and Crowell, 1967).

Direction of ice transport is indicated as W to E or SW to NE (present coordinates, Frakes and Crowell, 1967), on the basis of trends of linear sand bodies, sedimentary structures in intercalated strata, variation in clast size and diamictite thickness, and diamictite clast fabric.

Clast lithologies, summarized by Stone and Thomson (2005), include quartzite, sandstone, quartz, chert, shale, conglomerate, limestone, granites, gneiss, schist, slate, dolerite, porphyries, ignimbrite, and banded iron-stone.

The archaeocyathan limestone clasts studied by Stone and Thomson (2005) were collected around Hill Cove and Port Purvis (West Falkland/Gran Malvina Island, Figure 2) and Frying Pan Quarry, near Mount Pleasant Airport (East Falkland/Soledad Island, see also Stone, 2011). The archaeocyath fauna contained in limestone clasts is relatively well-preserved. Stone and Thomson (2005) recognized three informal species and discussed their general similarities to those known from Antarctica and erratic blocks in the Carboniferous Dwyka Tillite of South Africa. The systematic study of this fauna is in preparation (Thomson, personal communication, 2010). These authors concluded that the most likely source of the Falkland/Malvinas archaeocyath-bearing limestone clasts was the Transantarctic Mountains.

\subsection{North Patagonian Massif-Sierra Grande area}

The first documented records of archaeocyaths in continental South America are from Early Cambrian fossiliferous limestone blocks contained in a metaconglomerate of the Cambro-Ordovician El Jagüelito Formation, within the northern Patagonia basement of Argentina (Figures 1 and 2; González et al., 2011a). The low-grade El Jagüelito Formation is unconformably covered by Siluro-Devonian sandstones and quartzites of the Sierra Grande Formation (Busteros et al., 1998).

The metaconglomerate is a $c a .1100 \mathrm{~m}$ long by $10 \mathrm{~m}$ thick lenticular bed (González et al., 2011a). It is matrixsupported and normally graded, and contains rounded to sub-rounded cobbles and pebbles mainly of granitoids, intermediate to acidic volcanic rocks, mono- and polycrystalline quartz and metapelites. Rare and outsized (up to $1 \mathrm{~m}$ ) archaeocyath limestone clasts are subangular (Figure 3).

Seven Atdabanian-Botomian archaeocyath taxa were recovered from the El Jagüelito Formation (Figure 4). They have overall affinities with the Australo-Antarctic or 'Gondwana' palaeobiogeographic province, mainly with those described from the Shackleton Limestone involved in the Ross
Orogeny of the Transantarctic Mountains. They are also similar to those found in the blocks of the Late Carboniferous Fitzroy Tillite Formation in the Falkland/Malvinas Islands (Stone and Thomson, 2005, see below).

The El Jagüelito Formation metaconglomerate can be correlated with the Douglas Conglomerate (Goodge et al., 2004) of the Transantarctic Mountains, both containing coeval archaeocyathan limestone clasts. The comparison of lithology, archaeocyath fauna, stratigraphy and detrital zircon patterns (Naipauer et al., 2010) shows an intimate correlation between the El Jagüelito Formation (Patagonia, Argentina) and the Byrd and Beardmore groups (central Transantarctic Mountains), and suggests a common Ross orogenic history in East Gondwana during the CambroOrdovician (González et al., 2011b). As a result, Patagonia is proposed as a crustal block originated in the Ross Orogeny of the central Transantarctic Mountains during Cambro-Ordovician times, which subsequently shifted from East to West Gondwana (González et al., 2011c).

\subsection{Dubious localities}

Rusconi (1951, 1952) described a supposed archaeocyath species from the lower Palaeozoic of the southern Precordillera in Mendoza Province. The material was collected from Sierra de Salagasta, about $40 \mathrm{~km}$ North of Mendoza city (Figure 2), and consists of two sponge samples having a cylindrical shape and an internal net of irregularly distributed holes and furrows (Rusconi, 1952, figure 2; pl. 1, figure 1). These specimens were recorded in association with a high-diversity Late Cambrian-Early Ordovician (?) fauna which is dominated by crinoids and articulate brachiopods. Rusconi (1952) originally assigned the material to Spirocyathus Hinde, 1889 (=Archaeocyathus Billings, 1861), an irregular archaeocyath genus described from the lower and middle Cambrian of North America, Europe, Asia and Antarctic-Australia. However, the specimens from Sierra de Salagasta are characterized by having a reticulate exoskeleton and seem to lack genuine septa, suggesting affinities with Lithistida (Demospongea) rather than with Archaeocyatha.

Another record from the southernmost South America is restricted to a doubtful mention of Coscyanocyathus Bornemann (fossil collected by Lovisato, 1883; in Hyades, 1887, p. 222), from the Beauvoir Formation (Harrington, 1943; Caminos and Nullo, 1979) on Isla de Los Estados, east of Tierra del Fuego (Figure 2), and therefore referred to the Early Palaeozoic. This fossil was later dismissed as an archaeocyath, and referred to a cephalopod by Richter (1925; in Harrington, 1943). The latter author and Blasco and Levy (1975, in Caminos and Nullo, 1979) described and documented new cephalopod fossils from the Beauvoir 

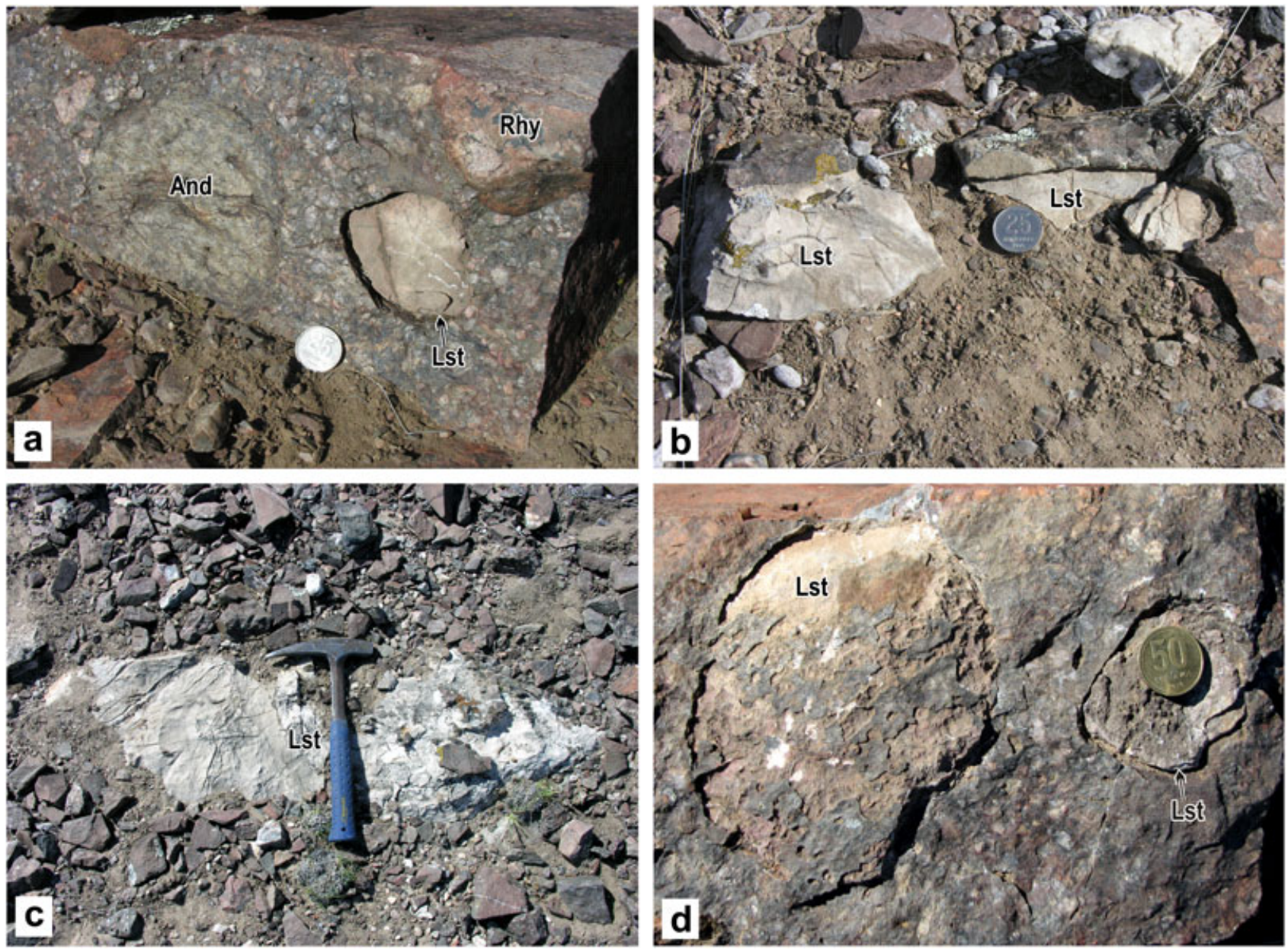

Figure 3. a to d, Archaeocyathan limestone clasts contained in a metaconglomerate of the Cambro-Ordovician El Jagüelito Formation, Sierra Grande area, northern Patagonia basement of Argentina. Lst: limestone clasts. Other clasts = And: andesite; Rhy: rhyolite. Diameter of coins: $2.5 \mathrm{~cm}$ (photographs a and b after González et al. (2011a), and reproduced by permission of the Editorial Office of Geologica Acta, Barcelona). This figure is available in colour online at wileyonlinelibrary.com/journal/gj

Formation and reassigned this unit to the Upper JurassicLower Cretaceous. Currently, there are no doubts about the Mesozoic age of the Beauvoir Formation, ruling out any presence of archaeocyaths in Isla de Los Estados.

\section{THE ARCHAEOCYATHS OF SAUCE GRANDE FORMATION}

\subsection{Local geology of the Sauce Grande Formation}

The Sauce Grande Formation is the lowermost unit of the Pillahuincó Group, which also includes the Piedra Azul, Bonete, and Tunas formations (Harrington, 1934, 1947, 1970). The Sauce Grande Formation overlies the meta-sandstones of the Lolén Formation (Ventana Group; Harrington, 1970) that bears a Malvinokaffric fauna of Devonian age (Harrington, 1947, 1980). In accordance with the fossil content recorded in the overlying Bonete Formation (Eurydesma fauna and Glossopteris flora), the age of the Pillahuincó Group is considered as Late Carboniferous to Early Permian (Harrington, 1934, 1955).

The Sauce Grande Formation crops out in a narrow NNW-SSE belt about $35 \mathrm{~km}$ long. Massive to poorly stratified diamictites are the predominant rocks, but conglomerates, quartz-sandstones, and shales are also present in smaller proportion (Figure 5). Since Keidel's (1916) work, the diamictites have been interpreted as having a glacial (Coleman, 1918; Du Toit, 1927; Harrington, 1947; Massabie and Rossello, 1984) or glacio-marine origin (Coates, 1969; Frakes and Crowell, 1969; Harrington, 1970, 1972). Keidel (1916) was also the first to suggest a possible correlation with deposits of the same origin and age in the Falkland/Malvinas Islands and in the Karoo Basin in South Africa.

The Sauce Grande diamictites are composed mainly of angular to rounded fragments of quartz-sandstone, with 

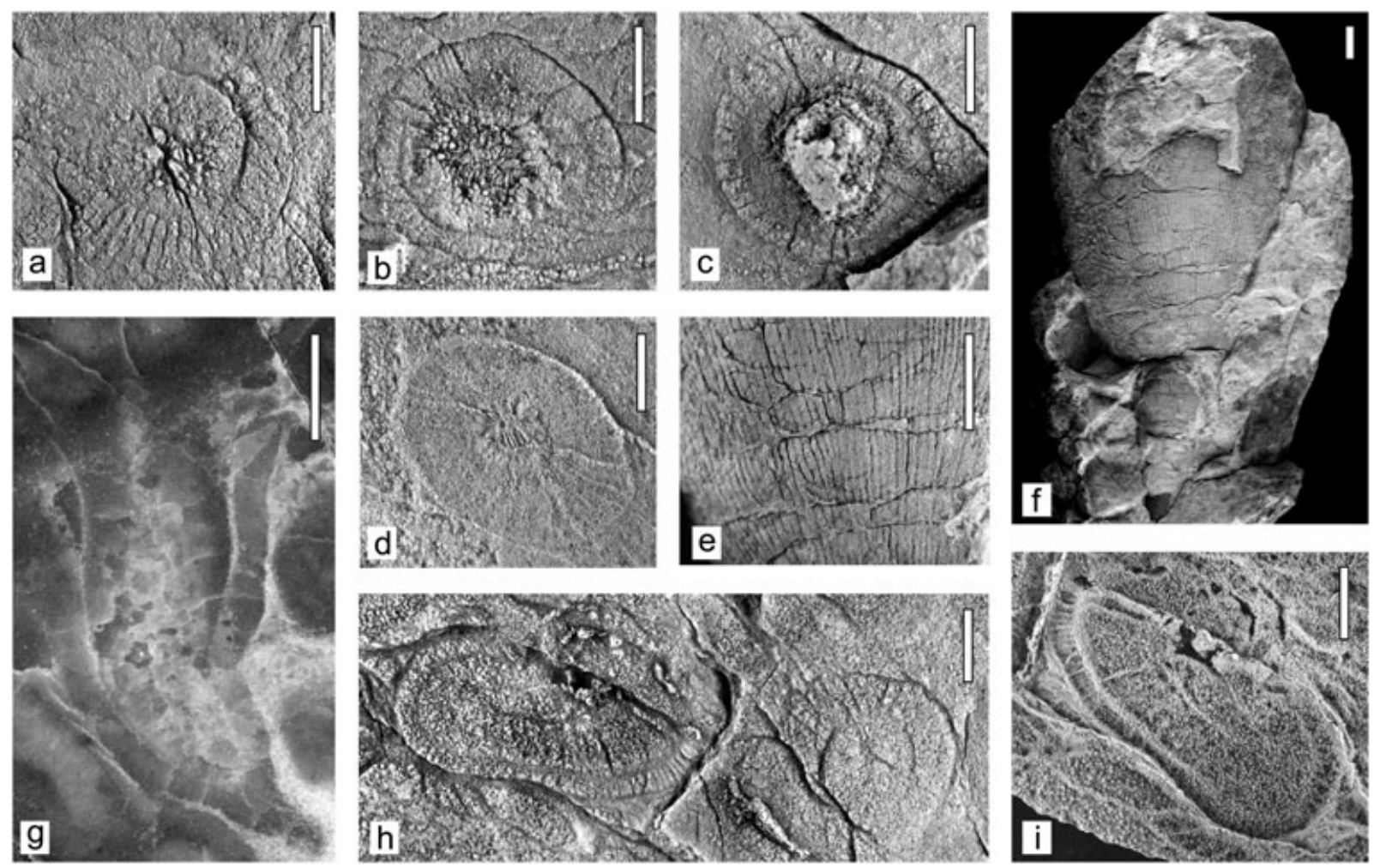

Figure 4. Archaeocyaths from limestone blocks of the El Jagüelito Formation, Sierra Grande, Río Negro Province, Argentina. a, Archaeocyatha sp. 1, MLP 32580-5a, transverse section. b, Archaeocyatha sp. 2, MLP 32580-1b, transverse section. c, Archaeocyatha sp. 3, MLP 32580-5c, transverse section. d, Archaeocyatha sp. 4, MLP 32580-1a, transverse section, latex cast. e, f, Archaeocyatha sp. 6, MLP 32581-1, detail (e) and general morphology (f). g, Archaeocyatha sp. 3, MLP 32580-1d, polished longitudinal section. h, Archaeocyatha sp. 5 (left), MLP 32580-3a, and Archaeocyatha sp. 1 (right), MLP 32580-5b, transverse section. i, Archaeocyatha sp. 5, MLP 32580-3a, transverse section, latex cast. Scale bars: $5 \mathrm{~mm}$ (photographs after González et al. (2011a), and reproduced by permission of the Editorial Office of Geologica Acta, Barcelona).

smaller proportions of shale, limestone (with archaeocyaths), quartz-feldspathic meta-sandstones and granitic and volcanic fragments of different composition (Massabie and Rossello, 1984; Andreis and Torres Ribeiro, 2003).

Palaeocurrent indicators are difficult to identify in the massive to poorly stratified diamictite. However, some channel orientation, clast imbrication, and ripple marks were measured (Andreis and Cladera, 1991; Andreis and Torres Ribeiro, 2003). According to those authors, and despite significant dispersion, principal palaeocurrent trends are oriented towards the $\mathrm{N}$ or NW (present coordinates), and hence direction of ice transport is indicated as $\mathrm{S}$ to $\mathrm{N}$ or SE to NW (present coordinates), coming from South Africa to South America (López-Gamundí and Rosello, 1998; Andreis and Torres Ribeiro, 2003), which is in turn coincident with the ice flow directions derived from Dwyka deposits in the Karoo Basin (Crowell and Frakes, 1972).

\subsection{Archaeocyath record}

The presence of limestone clasts in the Sauce Grande Formation has been known since the pioneering studies of Keidel (1916) and Schiller (1930). It is remarkable that
Keidel (1916, p. 21) highlighted the finding of 'one limestone clast containing coral fossils'. Unfortunately he did not study the fossils in detail, nor did he indicate the repository where they were housed. The possibility that Keidel's fossils were in fact archaeocyaths cannot be dismissed, and therefore this might be the first mention of archaeocyaths contained in a limestone clast from the Sauce Grande Formation of the Sierras Australes. In order to corroborate the suspicion, we performed a new systematic field search for archaeocyathan limestone clasts in glaciogenic deposits of the Sierras Australes of Buenos Aires.

Following the earlier mention of 'coral fossils' made by Keidel (1916), and allowing for detailed descriptions of clasts composition performed by Andreis (1965) and Andreis and Torres Ribeiro (2003), we recognized at least three localities with limestone clasts contained within diamictites of the Sauce Grande Formation. They are located between 1.0 and $2.6 \mathrm{~km}$ northeast of the bridge over the Sauce Grande creek, close to Villa Ventana. The localities (SV-1 to SV-3) are along the tracks of the Southern Railway, and the archaeocyath fauna was found only in one of them (SV-1, Lat. 38 $07^{\prime} 48.70^{\prime \prime}$ South. Long. 61 $46^{\prime} 40.90^{\prime \prime}$ West). Furthermore, only two limestone clasts containing archaeocyaths were found, out of the 18 recovered from this locality. 

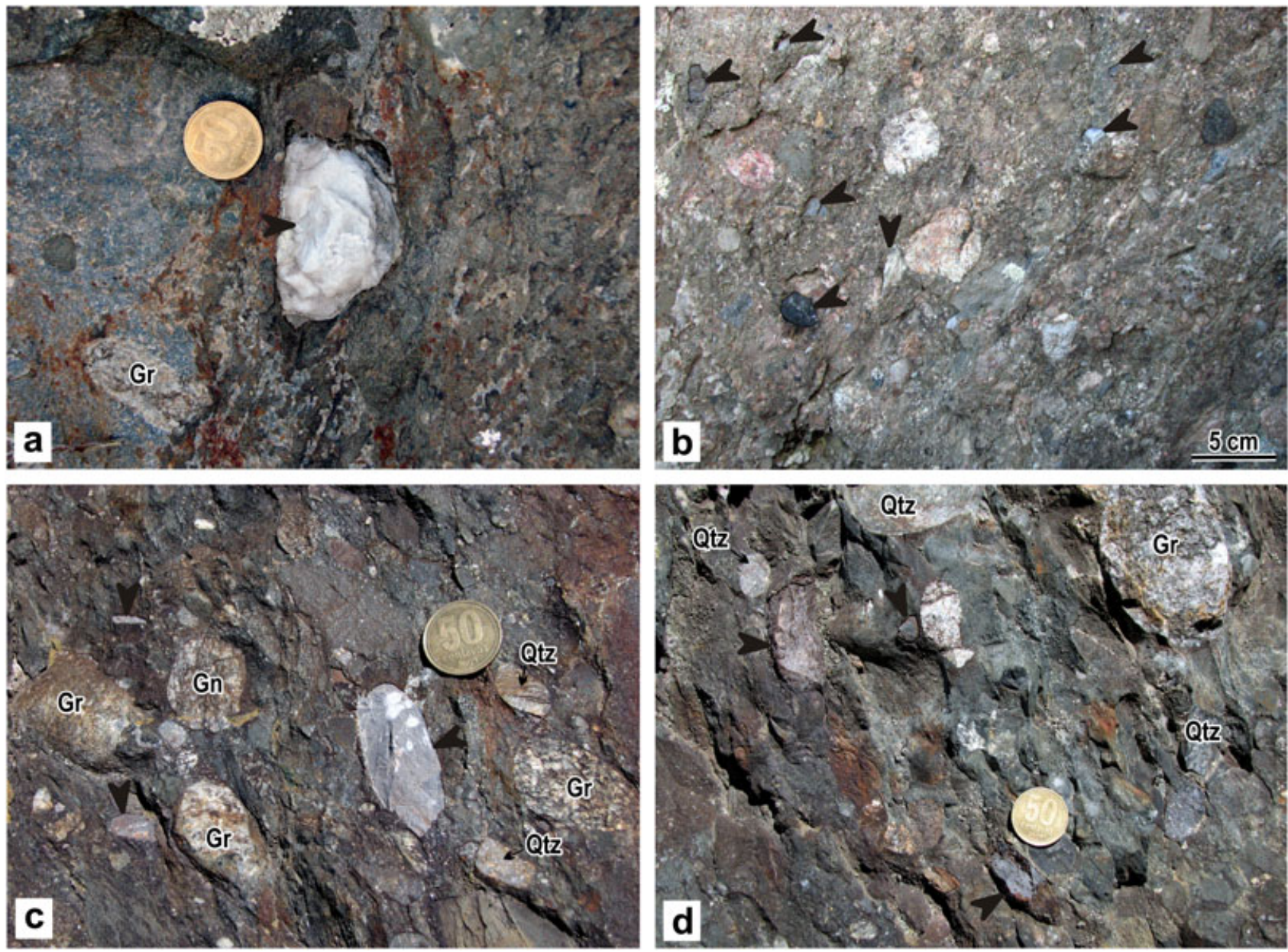

Figure 5. a to d, Diamictites of the Late Carboniferous Sauce Grande Formation from Sierras Australes of Buenos Aires. Massive to thinly laminated grey to white limestone clasts are indicated by arrows. $\mathbf{a}$ and $\mathbf{b}$ come from diamictite of the locality SV-1; $\mathbf{c}$ and $\mathbf{d}$ from conglomerate of the SV-2. Other clasts = Gr: granitoid, Gn: gneiss, Qtz: quartzite, diameter of coins: $2.5 \mathrm{~cm}$. This figure is available in colour online at wileyonlinelibrary.com/journal/gj

Preservation of all archaeocyaths is poor. They were first observed directly on hand-specimens of the limestone clasts, sometimes with the help of a thin coating of magnesium sublimate. The specimens were photographed with a digital reflex camera and 1:1 macro lens and are housed in the Invertebrate Palaeontology collections of the La Plata Natural History Museum (MLP 29220 to 29221), La Plata, Argentina.

The archaeocyaths consist of 11 specimens preserved as transverse sections on the naturally weathered surface of the clasts, together with a single conical cup that is partially isolated from the matrix. Although additional complete and well-preserved material is necessary to warrant a comprehensive systematic study, it is possible to recognize at least three different species, which are briefly outlined as follows:

The small-sized individuals illustrated in Figure $6 \mathrm{a}-\mathrm{c}$, e and $\mathrm{f}$ seem to be conspecific. They are characterized by having a maximum diameter of 3 to $4 \mathrm{~mm}$, a conic-cylindrical, slightly curved solitary cup which is subcircular to slightly ovoid in transverse section, a moderately wide intervallum, and a central cavity occupying about one-third of the cup diameter. The intervallum shows 14 complete, straight, thick and porous radial septa (Figure 6a), and the inner wall appears to have simple pores. The material illustrated in Figure $6 \mathrm{~g}$-left is closely similar to those specimens, although it differs by having a diameter of $6.5 \mathrm{~mm}$, a more ovoid outline, a larger intervallum, and 20 septa instead of 14 .

The specimen illustrated in Figure 6d has a maximum diameter of $25 \mathrm{~mm}$ and is characterized by its ovoid outline in transverse section, its very wide central cavity and its extremely reduced intervallum, which occupies only $6 \%$ of the cup maximum diameter. The inner wall of the cup looks sinuous. The septa are numerous and very close to each other, a condition that is especially evident in the 'bottom' and 'right' portion of Figure 6d. Although the septa shown in the 'top' and 'left' parts of that figure are more widely spaced, this might possibly be because the section is slightly oblique to the axis of the cup. Because of its large size, this specimen is the most conspicuous archaeocyath of the assemblage studied. 

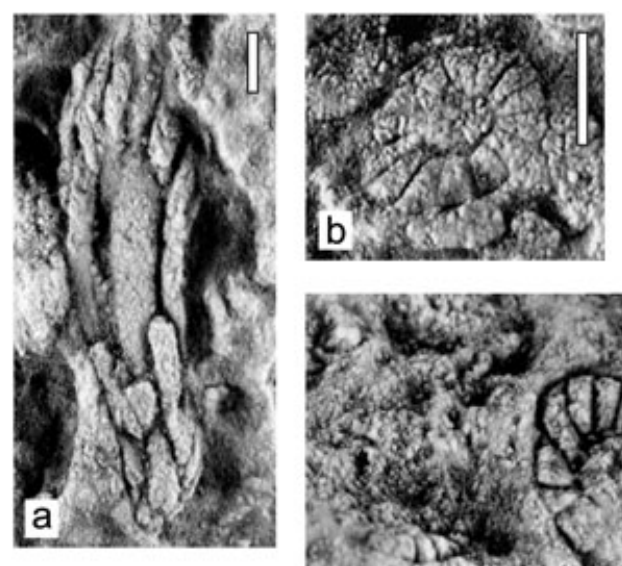

P. D. GONZÁLEZ ET AL.
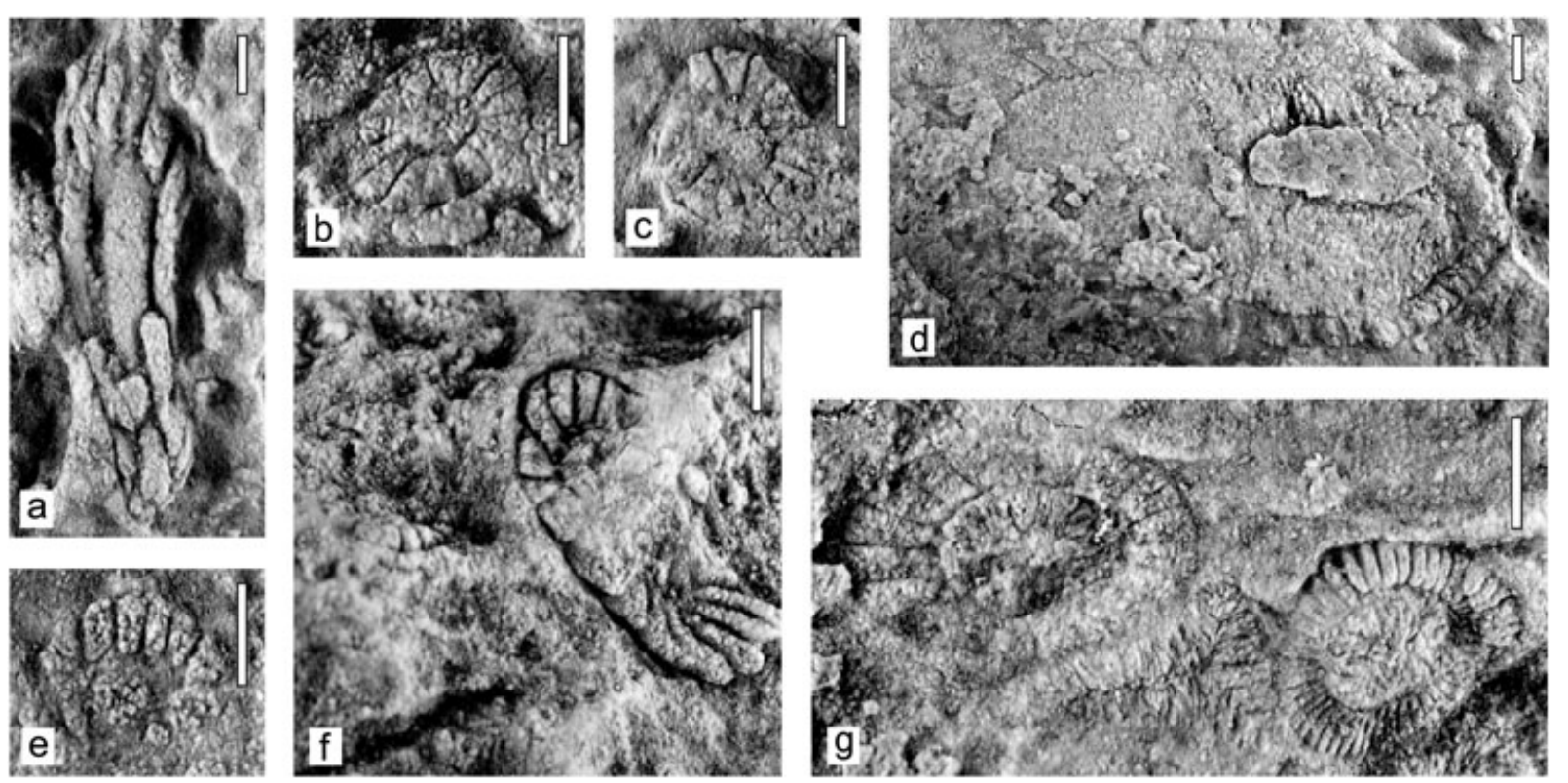

Figure 6. Archaeocyaths from limestone blocks of the Sauce Grande Formation, Sierras Australes of Buenos Aires, Buenos Aires Province, Argentina. Most specimens are preserved as transverse sections on naturally weathered surface, with the exception of a. At least three different species are represented in the collected material (see text). a, Longitudinal view of the cup, MLP 29220-a. b, MLP 29220-b. c, MLP 29220-c. d, MLP 29220-e. e, MLP 29220-d. f, MLP 29221. g, MLP 29220-f (left) and MLP 29220-g (right). Scale bars: 2 mm.

By contrast, the species represented by the specimen of Figure $6 \mathrm{~g}$-right shows a subcircular outline and a small size. The material possesses a diameter of $4.5 \mathrm{~mm}$, a relatively narrow intervallum occupying about $20 \%$ of the cup diameter, a correspondingly wide central cavity, and a large number of septa (44). The latter are straight, thick, and extended from the inner to the outer wall of the cup. The cup is longitudinally arched between septa.

Since the archaeocyaths from the Sauce Grande Formation are scarce and not well preserved, their generic and specific affinities are difficult to establish. However, the general morphology of the specimens illustrated in Figure 6a-c, e and $\mathrm{f}$ leads us to compare it particularly with Robustocyathus Zhuravleva. It mostly resembles juvenile samples from moraines of the Whichaway Nunataks, East Antarctica (inset of Figure 2; see Hill, 1965, pl. 3, figures 2b-left, 6, 8), by sharing a relatively wide intervallum and a similar pattern of septa. In the same way, the particular exoskeleton of Figure 6d shows major similarities with Archaeocyatha sp. 5 from the El Jagüelito Formation of the North Patagonian Massif (González et al., 2011a, figures 6B-left, C; Figure 4h-left, i), Ajacicyathus cf. ajax (Taylor), from the Shackleton Limestone of the Nimrod Glacier, in central Transantarctic Mountains (Figure 7; Debrenne and Kruse, 1986, figure 7), as well as undescribed material from a limestone block in the Fitzroy Tillite Formation from Falkland/Malvinas Islands (Stone and Thomson, 2005, figure A1.a, above left), by having an irregular outline in transverse section, a very wide central cavity and an extremely reduced intervallum. Finally, the specimen of Figure $6 \mathrm{~g}$-right mostly resembles Archaeocyatha sp. 2, from the El Jagüelito Formation of Patagonia (González et al., 2011a, figure 6A; Figure $4 \mathrm{~b}$ ), but differs by having a slightly smaller central cavity and a lower number of septa. This material is also superficially comparable to Thalamocyathus trachealis Gordon, from the lower Cambrian of South Australia and Antarctica (e.g. Hill, 1965, pl. 7, figures 2b, 8a), in possessing a similar intervallum/central cavity ratio, and a similar arrangement of septa. Thalamocyathus has been widely described from in situ Lower Cambrian limestones of the Transantarctic Mountains and South Australia, as well as from erratic blocks on King George Island, Whichaway Nunataks, the Weddell Sea and South Africa (Debrenne and Kruse, 1989; Figures 2 and 7). Thus, the archaeocyaths from the Sauce Grande Formation suggest general affinities with Early Cambrian assemblages of the Australo-Antarctic palaeobiogeographic province.

\section{THE ARCHAEOCYATHAN LIMESTONE BLOCKS OF THE SAUCE GRANDE FORMATION IN RELATION TO LATE PALAEOZOIC GONDWANA GLACIATION}

It is widely known that the Sauce Grande Formation of the Sierras Australes in South America is a close analogue of the Fitzroy Tillite Formation of Falkland/Malvinas Islands and of the Dwyka Tillite of South Africa (Keidel, 1916; Frakes and Crowell, 1967, 1969; Crowell and Frakes, 1972; Caputo and Crowell, 1985; Veevers and Powell, 




Figure 7. Reconstruction of the Gondwana supercontinent for the Late Carboniferous at $290 \mathrm{Ma}$ (after Powell and Li, 1994). Glacial episodes after Veevers and Powell (1987) and López-Gamundí (1997). Late Palaeozoic basins after López-Gamundí (2010) and many references therein. Ice-flow directions from Frakes and Crowell (1969) for South America (additional information of Sauce Grande Basin after López-Gamundí and Rosello, 1998, and Paraná Basin after Gesicki et al., 2002), from Crowell and Frakes (1972) for South Africa, from Frakes and Crowell (1969) for Falkland/Malvinas Islands, from Frakes et al. (1971) for Antarctica, and from Crowell and Frakes (1971) for Australia. In situ archaeocyaths locations in Antarctica and Australia are after Debrenne and Kruse (1989), Debrenne (2007), and references therein. Note the ice-flow direction from East to West Gondwana suggesting the possible Antarctic provenance of the allochthonous archaeocyaths contained in limestone erratics within Permo-Carboniferous glaciogenic rocks in West Gondwana. This figure is available in colour online at wileyonlinelibrary.com/journal/gj

1987; López-Gamundí and Rosello, 1998; López-Gamundí and Buatois, 2010). The most striking similarities are those related to their glaciogenic rocks, clast lithology, glacial lithofacies and source areas, in addition to their palaeoclimatic, palaeogeographic and palaeotectonic aspects related to Permo-Carboniferous Gondwanaland glaciation (Episode III, Veevers and Powell, 1987; López-Gamundí, 1997). In the Ellsworth Mountains of West Antarctica, the Whiteout Conglomerate represents the Permo-Carboniferous Gondwanaland glaciation (Webers et al., 1992), and hence is the time-stratigraphical equivalent of the formerly mentioned units.

A key feature shared by the Fitzroy Tillite Formation, the Dwyka Tillite, and the Whiteout Conglomerate is the rarity of the limestone clasts, which additionally contain the same archaeocyath fauna (Debrenne and Kruse, 1989; Stone and Thomson, 2005). The new find in the Sauce Grande Formation also shows this feature. Thus, the archaeocyath- bearing limestone clasts represent a further crucial element for the correlation of all those units across Gondwana.

The archaeocyaths in the Sauce Grande Formation provide further confirmation about the provenance of the limestone glacial erratics and establish their distribution farther west, as also supported by ice flow directions within the Permo-Carboniferous Gondwanaland glaciation (Figure 7). In this respect, Andreis and Torres Ribeiro (2003) already deduced that the glacier advanced from South Africa to South America.

The Transantarctic Mountains seems to have been the most likely source area for the Early Cambrian archaeocyathan limestone clasts found in South America and elsewhere in southern Gondwana, for a long period of time between Early Palaeozoic and Cenozoic times:

(1) In Early Palaeozoic times, the clasts formed part of the Cambro-Ordovician El Jagüelito Formation of Patagonia. 
Northern Patagonia is interpreted as being located adjacent to the Ross Orogen during Cambrian times (González et al., 2011b, 2011c), receiving the archaeocyathan limestone clasts derived from the Shackleton Limestone at a more outboard position with respect to the coeval Douglas Conglomerate described by Goodge et al. (2004). It is widely accepted that the Patagonia Terrane collided against South America in Permian times (see synthesis in Ramos, 2008).

(2) In Late Palaeozoic times, archaeocyath-bearing clasts were transported by ice during the Permo-Carboniferous glaciation (Episode III) that produced the glacial deposits of the Whiteout Conglomerate of Ellsworth Mountains in West Antarctica, the Fitzroy Tillite Formation of Falkland/Malvinas Islands, the Dwyka Tillite of South Africa, and the Sauce Grande Formation in South America. In a reconstruction of Gondwana ( 290 Ma, after Powell and Li, 1994) the coincidence of ice flow patterns across the Ellsworth Mountains, the Falkland/ Malvinas Islands, South Africa and South America suggests that the Permo-Carboniferous ice sheet flowed from the Transantarctic Mountains towards the West Gondwana, and also towards Australia (Figure 7).

(3) Finally, during Cenozoic times, not only the central Transantarctic Mountains but also the Argentina Range would have provided archaeocyathan limestone clasts. They too were probably transferred by ice to form part of the glacio-marine sediments of the Oligocene Polonez Cove and Early Miocene Cape Melville formations, as well as the recent moraines in the King George Island-South Shetland Islands (Figure 2; Morycowa et al., 1982; Wrona and Zhuravlev, 1996), the recent moraines in the Whichaway Nunataks, and the blocks dredged from the Weddell Sea (Gordon, 1920). According to Morycowa et al. (1982) and Wrona and Zhuravlev (1996), reconstructions of ice stream movement and iceberg drift, and the similarities in archaeocyath specimens, suggest the Argentina Range limestones as the source of most of the erratics of King George Island, the Weddell Sea, and Whichaway Nunataks (Figure 2).

\section{FURTHER POTENTIAL TARGETS FOR FINDING ARCHAEOCYATHAN LIMESTONE BLOCKS WITHIN THE LATE CARBONIFEROUS DIAMICTITES IN CONTINENTAL SOUTH AMERICA}

The Sauce Grande Formation is widely exposed in the Sierras Australes of Buenos Aires Province (Harrington, 1947; Andreis, 1965), and, therefore, other diamictite outcrops within these ranges might also provide archaeocyathan limestone clasts.
The Sauce Grande Formation diamictites are also present in the subsurface of the Colorado Basin (Juan et al., 1996; Gebhard, 2005), off-shore Buenos Aires Province (Borehole Puelches es-1, Figure 2). As a southeastern extension of the Sierras Australes outcrops, they may also represent a link to the Dwyka Tillite of South Africa (Figure 7), and are another potential site to search for archaeocyathan limestone clasts.

Allochthonous archaeocyathan limestone blocks in diamictites could even occur in other South American regions, such as the Chaco-Paraná and Paraná basins (Figure 7). The Permo-Carboniferous Upper Ordóñez Formation (subsurface of the Chaco-Paraná Basin; Figure 2) is composed of diamictites containing laminated grey limestone clasts (Russo et al., 1987; Winn and Steinmetz, 1998). The inferred glacial lithofacies and glacial to glacio-marine depositional palaeoenvironments are comparable to those of the Sauce Grande and Dwyka formations (Winn and Steinmetz, 1998), even though no archaeocyaths have been reported so far. Likewise, in the Paraná Basin, several diamictites of the Itararé Group (Holz et al., 2010) contain grey limestone clasts, at least one-third of which were locally derived from underlying limestones (Frakes and Crowell, 1969). Nevertheless, an Antarctic provenance cannot be completely ruled out, taking into consideration the mostly ESE to WNW ice-flow directions proposed for the Permo-Carboniferous Gondwana glaciation (Episode III, Figure 7) in these basins (Frakes and Crowell, 1969; Gesicki et al., 2002). It is indeed possible that the limestone clasts from the Upper Ordóñez Formation and equivalent units (e.g. Itararé Group) share an Antarctic provenance with those of the Sauce Grande and Dwyka formations (Figure 7). In order to confirm this, archaeocyaths with Australo-Antarctic palaeobiogeographic affinities need to be found.

The Gondwanic diamictites from the Calingasta-UspallataRío Blanco and western Paganzo basins (Figure 7) of the Argentine Precordillera also bear limestone clasts, but their provenance is clearly local, from Cambrian and Ordovician limestone units underlying the diamictites (Frakes and Crowell, 1969; López-Gamundí and Martínez, 2000; Marenssi et al., 2005; Pérez Loinaze et al., 2010). Furthermore, the glaciation in those areas is somewhat older (Episode II of Veevers and Powell, 1987 and López-Gamundí, 1997, see Figure 7) than the Late Carboniferous-Early Permian episode, and thus, the glacial deposits are not contemporaneous with the Sauce Grande Formation (see figure 1 in López-Gamundí and Martínez, 2000).

Striking similarities between the Cambrian faunas in carbonate lithofacies of western Argentina and North America have been addressed in the literature (e.g. Harrington and Leanza, 1943; Rusconi, 1956; Poulsen, 1960; Borrello, 1971; Bordonaro, 2003 and references therein). Archaeocyaths are known in association with the Olenellus fauna in North America (Landing and Bartowski, 1996), but they have not been reported yet in the late Early Cambrian of the 
Precordillera of western Argentina. If archaeocyaths were found in those limestones (or in limestone blocks contained in diamictites), they might be expected to have Laurentian affinities (Nitecki, 1967), rather than Australo-Antarctic ones, given that the Precordillera, as part of the composite Cuyania Terrane, appears to be a piece detached from Laurentia (Ramos, 2004).

Finally, the Gondwanic units with diamictite horizons from the Tepuel-Genoa Basin in extra-Andean Patagonia (Figure 7) also bear rare limestone clasts (Frakes and Crowell, 1969). However, they are comparable to diamictites of similar age and lithofacies associations of the Precordillera, and thus they also belong to the early Late Carboniferous Glacial Episode II (López-Gamundí, 1987; López-Gamundí and Martínez, 2000).

\section{CONCLUDING REMARKS}

We report here the first finding of archaeocyath-bearing limestone blocks contained in diamictites of the Sauce Grande Formation, Sierras Australes of Buenos Aires Province, Argentina. To date, in situ Early Cambrian archaeocyathan limestones are unknown from South America. The recovered fauna is allochthonous and its most likely source is the Shackleton Limestone in the Transantarctic Mountains, as suggested by its overall affinities with Early Cambrian archaeocyath assemblages of the Australo-Antarctic palaeobiogeographic province.

The similar Antarctic provenance of the limestone clasts strengthens the geological correlation between the Sauce Grande, Dwyka and Fitzroy Tillite formations deposited during the Late Palaeozoic Gondwana glaciation. The new record of archaeocyathan limestone clasts in Sierras Australes, suggests that the distribution of these limestones, derived from East Antarctica, reached more western localities than previously known.

Allochthonous archaeocyath faunas constitute a key biological feature to be considered in palaeobiogeographic Gondwana reconstructions.

\section{ACKNOWLEDGEMENTS}

This is a contribution to the Special Issue and we thank Guillermo Albanesi for his kind invitation to publish our results in this volume. We are grateful to the reviewers, M. R.A. Thomson and O. López-Gamundí, whose comments contributed to improve the manuscript. The final English version was greatly benefited by the kind assistance of both reviewers. This study was funded by projects UNLP 11/N 528 and CONICET PIP 0119, Argentina.

\section{REFERENCES}

Aldiss, D.T., Edwards, E.J. 1999. The geology of the Falkland Islands. British Geological Survey Technical Report, WC/99/I0.

Amante, C., Eakins, B.W. 2009. ETOPO1 1 arc-minute global relief model: procedures, data sources and analysis. NOAA Technical Memorandum NESDIS NGDC-24, 19 pp.

Andreis, R.R. 1965. Petrografía de las sedimentitas psefíticas Paleozoicas de las Sierras Australes Bonaerenses. Anales de la Comisión de Investigaciones Científicas de la Provincia de Buenos Aires 6, 9-63.

Andreis, R.R., Cladera, G. 1991. Las epiclastitas Pérmicas de la Cuenca Sauce Grande (Sierras Australes, Buenos Aires), Argentina. Parte I: Composición y procedencia de los detritos. $4^{\circ}$ Reunión Argentina de Sedimentología 1, 127-134.

Andreis, R.R., Torres Ribeiro, M. 2003. Estratigrafia, facies y evolución depositacional de la Formación Sauce Grande (Carbonífero Superior), Cuenca Sauce Grande, Sierras Australes, Buenos Aires, Argentina. Revista de la Asociación Geológica Argentina 58, 137-165.

Baker, H.A. 1924. Final report on Geological Investigations in the Falkland Islands, 1920-1922. Government Printer, Stanley.

Billings, E. 1861. New species of Lower Silurian fossils: on some new or little known species of Lower Silurian fossils from the Potsdam Group (Primordial zone). Geological Survey of Canada (Montreal), 24 pp., 25 text-figs.

Blasco, G., Levy, R. 1975. Paleontología de la Formación Beauvoir. Servicio Geológico Nacional, unpublished report.

Bordonaro, O. 2003. Review of the Cambrian Stratigraphy of the Argentine Precordillera. Geologica Acta 1(1), 11-21.

Borrello, A.V. 1971. The Cambrian of South America. In: Cambrian of the New World, Holland, C.H. (ed.). Wiley Intersciences: Cardiff 1, 385-438.

Busteros, A., Giacosa, R., Lema, H. 1998. Hoja Geológica 4166-IV, Sierra Grande (Río Negro). IGRM-SEGEMAR. Boletín 241, 75.

Caminos, R., Nullo, F. 1979. Descripción Geológica de la Hoja 67e, Isla de Los Estados, Territorio Nacional de la Tierra del Fuego, Antártida e Islas del Atlántico Sur. Servicio Geológico Nacional, Boletín 175, 52.

Caputo, M.V., Crowell, J.C. 1985. Migration of glacial centers across Gondwana during Paleozoic Era. Geological Society of America Bulletin 96, 1020-1036.

Coates, D.A. 1969. Stratigraphy and sedimentation of the Sauce Grande Formation, Sierra de la Ventana, Southern Buenos Aires Province. Gondwana Stratigraphy, IUGS Symposium, Buenos Aires, 1967. UNESCO, 2, 799-816.

Coleman, A.P. 1918. Permo-Carboniferous glacial deposits of South America. Journal of Geology 26, 310-324.

Crowell, J.C., Frakes, L.A. 1971. Late Paleozoic Glaciation: Part IV, Australia. Geological Society of America Bulletin 82, 2515-2540.

Crowell, J.C., Frakes, L.A. 1972. Late Paleozoic Glaciation: Part V, Karroo Basin, South Africa. Geological Society of America Bulletin 83, $2887-2912$.

Debrenne, F. 2007. Lower Cambrian archaeocyathan bioconstructions. Comptes Rendus Palevol 6, 5-19.

Debrenne, F., Kruse, P.D. 1986. Shackleton limestone archaeocyaths. Alcheringa 10, 235-278.

Debrenne, F., Kruse, P.D. 1989. Cambrian Antarctic archaeocyaths. In: Origin and Evolution of the Antarctic Biota, Crame, J.A. (ed.). Geological Society, London, Special Publications 47, 15-28.

Du Toit, A.L. 1927. A geological comparison of South America with South Africa. Publications of the Carnegie Institute, Washington 381, 1-157.

Frakes, L.A., Crowell, J.C. 1967. Facies and paleogeography of Late Paleozoic Diamictite, Falkland Islands. Geological Society of America Bulletin 78, 37-58.

Frakes, L.A., Crowell, J.C. 1969. Late Paleozoic Glaciation: I, South America. Geological Society of America Bulletin 80, 1007-1042.

Frakes, L.A., Matthews, J.L., Crowell, J.C. 1971. Late Paleozoic Glaciation: III, Antarctica. Geological Society of America Bulletin 82, 1581-1604.

Gebhard, I. 2005. Geología y aspectos exploratorios de la Cuenca del Colorado. In: Geología y Recursos Minerales de la Provincia de Buenos Aires, de Barrio, R.E., Etcheverry, R.O., Caballé, M.F., Llambías, E.J. (eds). Relatorio $16^{\circ}$ Congreso Geológico Argentino: La Plata, 30, $447-458$. 
Gesicki, A.L., Riccomini, C., Boggiani, P.C. 2002. Ice flow direction during late Paleozoic glaciation in western Paraná Basin, Brazil. Journal of South American Earth Sciences 14, 933-939.

González, P.D., Tortello, M.F., Damborenea, S.E. 2011a. Early Cambrian archaeocyathan limestone blocks in low-grade meta-conglomerate from El Jagüelito Formation (Sierra Grande, Río Negro, Argentina). Geologica Acta 9(2), 159-173.

González, P.D., Sato, A.M., Naipauer, M., Varela, R., Llambías, E. Greco, G., González, S., García, V.. 2011b. Conexión Macizo Norpatagónico-Antártida Oriental: fósiles Arqueociátidos, comparación geológica y circones detríticos. $18^{\circ}$ Congreso Geológico Argentino Actas en CD: Neuquén, 87-88.

González, P.D., Sato, A.M., Naipauer, M., Varela, R., Llambías, E., Basei, M., Sato, K., Sproesser, W. 2011c. Does Patagonia represent a missing piece detached from the Ross Orogen? In: Gondwana 14 (East meet West), Schmitt, R.S., Trouw, R., Carvalho, I.S., Collins, A. (eds). Abstracts, Universidade Federal do Rio de Janeiro: Rio de Janeiro, Brazil, 153.

Goodge, J., Williams, I., Myrow, P. 2004. Provenance of Neoproterozoic and lower Paleozoic siliciclastic rocks of the central Ross orógeno Antarctica: Detrital record of rift-, passive- and active-margin sedimentation. Geological Society of America Bulletin 116(9/10), 1253-1279.

Gordon, W.T. 1920. Scottish National Antarctic Expedition 1902-1904: Cambrian organic remains from a dredging in the Weddell Sea. Transactions of the Royal Society of Edinburgh 52, 681-714.

Harrington, H.J. 1934. Sobre la presencia de restos de la flora de Glossopteris en las Sierras Australes de Buenos Aires y su significación en lo referente a las relaciones de la Serie Glacial y series superiores. Revista del Museo de La Plata 34, 303-338.

Harrington, H.J. 1943. Observaciones geológicas en la Isla de Los Estados. Anales del Museo Argentino de Ciencias Naturales 41, 29-52.

Harrington, H.J. 1947. Explicación de las Hojas Geológicas 33 m y 34 m, Sierras de Curamalal y de la Ventana, Provincia de Buenos Aires. Boletín Servicio Nacional de Minería y Geología Buenos Aires 61, 1-43.

Harrington, H.J. 1955. The Permian Eurydesma fauna of Eastern Argentina. Journal of Paleontology 29, 112-128.

Harrington, H.J. 1970. Las Sierras Australes de Buenos Aires, República Argentina: cadena aulacogénica. Revista de la Asociación Geológica Argentina 25, 151-181.

Harrington, H.J. 1972. Sierras Australes de Buenos Aires. In: Geología Regional Argentina, Leanza, A.F. (ed.). Academia Nacional de Ciencias: Córdoba; 395-405.

Harrington, H.J. 1980. Sierras Australes de la Provincia de Buenos Aires. In: $2^{\circ}$ Simposio de Geología Regional Argentina, Academia Nacional de Ciencias: Córdoba 2: 967-983.

Harrington, H.J., Leanza, A.F. 1943. Paleontología del Paleozoico inferior de la Argentina. 1. Las faunas del Cámbrico Medio de San Juan. Revista del Museo de La Plata 2(11), 207-223.

Hill, D. 1965. Geology 3. Archaeocyatha from Antarctica and a review of the phylum. Transantarctic expedition 1955-1958, Scientific Reports 10, 1-151.

Hill, D. 1972. Part E (revised), 1. Archaeocyatha. In: Treatise on Invertebrate Paleontology, Teichert C. (ed.). The Geological Society of America and the University of Kansas: Boulder, Colorado, 158 pp.

Hinde, G.J. 1889. On Archaeocyathus Billings, and on other Genera, allied to or associated with it, from the Cambrian strata of North America, Spain, Sardinia and Scotland. Quarterly Journal of the Geological Society of London 45, 125-148. pl. 5

Holz, M., França, A.B., Souza, P.A., Iannuzzi, R., Rohn, R. 2010. A stratigraphic chart of the Late Carboniferous/Permian succession of the eastern border of the Paraná Basin, Brazil, South America. Journal of South American Earth Sciences 29, 381-399.

Hyades, P.. 1887. Mission Scientifique du Cap Horn (1882-83). Géologie 4, Paris, 249 pp.

James, N.P., Debrenne, F. 1981. Lower Cambrian bioherms: pioneer reefs of the Phanerozoic. Acta Paleontologica Polonica 25(3/4), 655-668.

Juan, R., de Jager, J., Rusell, J., Geghard, I. 1996. Flanco Norte de la Cuenca del Colorado. In: Geología y Recursos Naturales de la Plataforma Continental Argentina, Ramos, V.A., Turic, M.A. (eds.). Relatorio $13^{\circ}$ Congreso Geológico Argentino y $3^{\circ}$ Congreso de Exploración de Hidrocarburos: Buenos Aires, 7, 117-133.
Keidel, J. 1916. La geología de las sierras de la Provincia de Buenos Aires y sus relaciones con las montañas de Sud África y Los Andes. Anales del Ministerio de Agricultura de la Nación, Sección Geología, Mineralogía y Minería 11(3), 78.

Landing, E., Bartowski, K.E. 1996. Oldest shelly fossils from the Taconic allochthon and late Early Cambrian sea-levels in Eastern Laurentia. Journal of Paleontology 70(5), 741-761.

López-Gamundí, O. 1987. Depositional models for the glacial-marine sequences of Andean Late Paleozoic basins of Argentina. Sedimentary Geology 52, 109-126.

López-Gamundí, O. 1997. Glacial-postglacial transition in the late Paleozoic basins of southern South America. In: Late Glacial and Postglacial Environmental Changes, Quaternary, Carboniferous-Permian and Proterozoic, Martini, I.P. (ed.). UK, Oxford University Press: Oxford; $147-168$.

López-Gamundí, O. 2010. Transgressions related to the demise of the Late Paleozoic Ice Age: Their sequence stratigraphic context. In: Late Paleozoic glacial events and postglacial transgressions in Gondwana, López-Gamundí, O.R., Buatois, L.A. (eds). Geological Society of America: Boulder, Colorado (USA) Special Paper 468, 1-35.

López-Gamundí, O., Rosello, E.A. 1998. Basin fill evolution and paleotectonic patterns along the Samfrau geosyncline: the Sauce Grande basinVentana fold belt (Argentina) and Karoo basin-Cape fold belt (South Africa) revisited. Geologische Rundschau 86, 819-834.

López-Gamundí, O., Martínez, M. 2000. Evidence of glacial abrasion in the Calingasta-Uspallata and western Paganzo basins, mid-Carboniferous of western Argentina. Palaeogeography, Palaeoclimatology, Palaeoecology 159, 145-165.

López-Gamundí, O.R., Buatois, L.A. 2010. Introduction: Late Paleozoic glacial events and postglacial transgressions in Gondwana. In: Late Paleozoic glacial events and postglacial transgressions in Gondwana, López-Gamundí, O.R., Buatois, L.A. (eds). Geological Society of America, Special Paper 468, v-viii.

Lovisato, D.. 1883. Una escurzione geologica nella Patagonia e nella Terra del Fuoco. Bolletino della Societa Geografica Italiana. Serie II, Vol VIII, fasc. 5 e 6 .

Marenssi, S.A., Tripaldi, A., Limarino, C.O., Caselli, A.T. 2005. Facies and architecture of a Carboniferous grounding-line system from the Guandacol Formation, Paganzo Basin, Northwestern Argentina. Gondwana Research 8(2), 187-202.

Massabie, A.C., Rossello, E.A. 1984. La discordancia pre-Formación Sauce Grande y su entorno estratigráfico, Sierras Australes de Buenos Aires, Argentina. $9^{\circ}$ Congreso Geológico Argentino 1, 337-352.

Morycowa, E., Rubinowski, Z., Tokarski, A.K. 1982. Archaeocyathids from a moraine at Three Sisters Point, King George Island (South Shetland Islands, Antarctica). Studia Geologica Polonica 74(3), 73-80.

Naipauer, M., Sato, A.M., González, P.D., Chemale Jr., F., Varela, R., Llambías, E., Greco, G., Dantas, E. 2010. Eopaleozoic Patagonia-East Antarctica connection: fossil and U-Pb evidence from El Jagüelito Formation. 7th South American Symposium on Isotope Geology, Short Papers Volume (CD): Brasília, 602-605.

Nitecki, M.H. 1967. Bibliographic index of North American archaeocyathids. Fieldiana: Geology, Publication of the Field Museum of Natural History 17(2), 107-220.

Pérez Loinaze, V.S., Limarino, C.O., Césari S.N. 2010. Glacial events in Carboniferous sequences from Paganzo and Río Blanco Basins (Northwest Argentina): palynology and depositional setting. Geologica Acta 8(4), 399-418.

Poulsen, C. 1960. Fossils from the late Middle Cambrian Bolaspidella Zone of Mendoza, Argentina. Matematisk-fysiske Meddelelser, Det Kongelige Danske Videnskabernes Selskab 32(11), 1-42.

Powell, C.M., Li, Z.X. 1994. Reconstruction of the Panthallasan margin of Gondwanaland. In: Permian-Triassic Pangean basins and foldbelts along the Panthallasan margin of Gondwanaland, Veevers J.J., Powell, C.M. (eds). Geological Society of America Memoir, 184, 5-9.

Ramos, V.A. 2004. Cuyania, an exotic block to Gondwana: review of a historical success and the present problems. Gondwana Research 7(4), 1009-1026. 
Ramos, V.A. 2008. Patagonia: a Paleozoic continent adrift? Journal of South American Earth Sciences 26, 235-251.

Richter, M. 1925. Beiträge zur Kenntnis der Kreide im Feuerland. Neues Jahrbuch für Mineralogie, Geologie und Paläontologie, B.B. 52, 524-568.

Rusconi, C. 1951. Fósiles cámbricos de Salagasta, Mendoza. Anales de la Sociedad Científica Argentina 152, 255-264.

Rusconi, C. 1952. Los fósiles cámbricos de Salagasta, Mendoza. Revista del Museo de Historia Natural de Mendoza 6, 19-62. pls. 1-4.

Rusconi, C. 1956. Correlaciones Cambro-Ordovícicas entre Mendoza y Norteamérica. $20^{\circ}$ Congreso Geológico Internacional, Simposio Cámbrico, México, 2, 751-762.

Russo, A., Archangelsky, S., Andreis, R.R., Cuerda, A. 1987. El sistema Carbonífero en la República Argentina. In: Upper Paleozoic of South America, Archangelsky, S. (ed.). IGCP 211, Academia Nacional de Ciencias: Cordoba, 183-198.

Schiller, W. 1930. Resultados Estratigráficos. Anales del Museo de La Plata. Segunda Parte, Geología I, 46-82.

Stone, P., Thomson, M.R.A. 2005. Archaeocyathan limestone blocks of likely Antarctic origin in Gondwanan tillite from the Falkland Islands. In: Terrane Processes at the Margins of Gondwana, Vaughan, A.P., Leat,
P.T., Pankhurst, R.J. (eds). Geological Society, London, Special Publications 246(1), 347-357.

Stone, P. 2011. Borehole core recovered from the Late Carboniferous to Early Permian Fitzroy Tillite and Port Sussex formations, Falkland Islands: geological background and sample details. British Geological Survey Internal Report, Marine Geoscience Programme OR/11/028, 19 pp.

Veevers, J.J., Powell, C.M. 1987. Late Paleozoic glacial episodes in Gondwanaland reflected in transgressive-regressive depositional sequences in Euramerica. Geological Society of America Bulletin 98, 475-487.

Webers, G.F., Craddock, C., Splettstoesser, J.F. 1992. Geologic history of the Ellsworth Mountains, West Antarctica. In: Geology and Paleontology of the Ellsworth Mountains, West Antarctica, Webers, G.F., Craddock, C., Splettstoesser, J.F. (eds). Geological Society of America, Memoir 170, 1-8.

Winn, R.D., Steinmetz, J.C. 1998. Upper Paleozoic strata of the ChacoParaná basin, Argentina, and the great Gondwana glaciation. Journal of South American Earth Sciences 11(2), 153-168.

Wrona, R., Zhuravlev, A.Y. 1996. Early Cambrian archaeocyaths from glacial erratics of King George Island (South Shetland Islands), Antarctica. Palaeontologia Polonica 55, 9-36. 